\title{
Beberapa Aspek Biologi Reproduksi Rajungan (Portunus pelagicus) di Perairan Betahwalang Demak
}

\author{
Hargo Seno Wahyu Edi*, Ali Djunaedi dan Sri Redjeki \\ Departemen IImu Kelautan, Fakultas Perikanan dan IImu Kelautan, Universitas Diponegoro \\ Jl. Prof. Soedarto, SH. Tembalang, Semarang 50275 \\ Email: hargo.seno@gmail.com
}

\begin{abstract}
Biological Aspects of Reproduction of Rajungan (Portunus pelagicus) in Betahwalang Demak

The waters of Betahwalang, Demak have quite potential cruise resources. For the sustainability of crab resources, sustainable management is necessary to do. Information on biology reproduction of crabs is required. The purpose of this research was to determine aspects of biology reproduction such as sex ratio, growth pattern and gonad maturity level of the crabs in Betahwalang waters. This research was conducted on 23 September - 29 October 2016 in Betahwalang, Demak. The method used in this research is descriptive research method. Determination of location observation is divided into 3 Station that is Station 1 depth between 1-10 $\mathrm{m}$, Station 2 depth 11-20 $\mathrm{m}$, and Station 3 depth 21-30 m. The data were collected by determination of gender, width and length of carapace, gonad maturity level and data of the environmental parameter. Results of the analysis showed that the male genital sex ratios were higher at Station 1 (2.87:1) than Station $2(1: 1.27)$ and $3(1: 1.65)$. The growth properties of male and female crabs on all three stations exhibit negative allometric growth properties. The percentage of female crab gonad maturity level at Station $2(94,31 \%)$ and $3(95,48 \%)$ higher than Station 1 $(30,43 \%)$.
\end{abstract}

Keywords: Biological Aspect Reproduction, Portunus pelagicus, Betahwalang, Demak

\section{Abstrak}

Wilayah perairan Betahwalang, Demak memiliki sumberdaya rajungan yang cukup potensial. Untuk kelestarian sumberdaya rajungan, perlu dilakukan dengan pengelolaan perikanan rajungan berkelanjutan. Dibutuhkan informasi tentang aspek biologi reproduksi rajungan sangat diperlukan. Tujuan penelitian ini adalah untuk mengetahui aspek biologi reproduksi seperti nisbah kelamin, pola pertumbuhan dan tingkat kematangan gonad rajungan di perairan Betahwalang. Penelitian ini dilaksanakan pada tanggal 23 September - 29 Oktober 2016 di perairan Betahwalang, Demak. Metode yang digunakan dalam penelitian ini adalah metode penelitian deskriptif. Penentuan lokasi pengamatan dibagi menjadi 3 Stasiun yaitu Stasiun 1 kedalaman antara 1-10 m, Stasiun 2 kedalaman 11-20 m, dan Stasiun 3 kedalaman 21-30 m. Pengambilan data penelitian meliputi penentuan jenis kelamin, lebar dan panjang karapas, tingkat kematangan gonad serta data parameter lingkungan. Hasil penelitian menunjukkan bahwa nisbah kelamin rajungan jantan lebih tinggi pada Stasiun $1 \quad(2,87: 1)$ daripada Stasiun $2(1: 1,27)$ dan $3(1: 1,65)$. Sifat pertumbuhan rajungan jantan dan betina pada ketiga Stasiun menunjukkan sifat pertumbuhan allometrik negatif. Persentase tingkat kematangan gonad rajungan betina pada Stasiun $2(94,31 \%)$ dan $3(95,48 \%)$ lebih tinggi daripada Stasiun 1 (30,43\%).

Kata kunci : Aspek Biologi Reproduksi, Portunus pelagicus, Betahwalang, Demak.

\section{PENDAHULUAN}

Rajungan (Portunus pelagicus) merupakan komoditas yang penting karena mempunyai nilai ekonomi tinggi dan permintaan pasar baik di dalam maupun luar negeri masih tinggi. Volume ekspor rajungan di 
Indonesia mengalami peningkatan dari tahun 2014 sampai tahun 2016 yaitu 10,8 juta ton menjadi 19,4 juta ton (APRI, 2017). Produk yang diekspor sebagian besar berupa daging rajungan beku dimana produk tersebut dapat berasal dari rajungan ukuran kecil sampai rajungan matang telur (Jacoeb et al., 2012).

Permintaan ekspor yang tinggi akan mendorong terjadinya eksploitasi sumber daya rajungan, yang berasal dari alam. Eksploitasi yang intensif dan kurang selektif akan mengakibatkan terganggunya keseimbangan populasi rajungan di alam dan berdampak terhadap penurunan potensi stok sumber daya rajungan. Potensi stok sumberdaya rajungan tergantung oleh beberapa faktor, diantaranya potensi stok yang akan memijah dan produktivitas rajungan yang berkaitan dengan intensitas eksploitasi yang tinggi (Lipcius dan Stockhausen, 2002).

Wilayah perairan Betahwalang, Demak memiliki sumberdaya rajungan yang cukup potensial. Namun sampai saat ini belum ada pengaturan zonasi dan waktu penangkapan yang diduga mengakibatkan penurunan produktivitas rajungan. Hal ini bisa dikarenakan dengan intensitas eksploitasi rajungan yang tinggi di perairan Betahwalang yaitu mulai dari perairan pesisir yang dangkal sampai ke perairan tengah laut. Hasil tangkapan rajungan di Betahwalang pada tahun 2009 sebesar $40 \mathrm{~kg}$ dalam satu kali melaut. Pada tahun 2014 tangkapan semakin sedikit yaitu sebesar $7 \mathrm{~kg}$. Keadaan tersebut diperburuk dengan tidak ada pendataan mengenai hasil tangkapan rajungan , sehingga pemerintah daerah setempat sulit untuk menentukan kebijakan (Istikasari et al., 2016).

Penurunan jumlah rajungan di alam dapat terlihat dengan ukuran rajungan yang matang gonad menjadi lebih kecil dimana rajungan muda berukuran $<100 \mathrm{~mm}$ sudah dapat menghasilkan gonad dan mampu bereproduksi. Oleh sebab itu, untuk menjaga kelestarian rajungan diperairan Betahwalang diperlukan pengelolaan berkelanjutan serta dibutuhkan informasi yang cukup tentang biologi reproduksi rajungan.

\section{MATERI DAN METODE}

Materi penelitian adalah 558 ekor rajungan (Portunus pelagicus) yang diperoleh nelayan dari perairan Betahwalang, Demak. Metode yang digunakan dalam penelitian ini adalah metode penelitian deskriptif. Pengambilan data dilakukan sebanyak 12 trip dengan 3 alat penangkapan yang berbeda, antara lain Jaring, Arad, dan Bubu. Ketiga alat penangkapan beroperasi pada kedalaman yang berbeda yaitu alat tangkap Jaring dengan kedalaman 1-10 m, alat tangkap Arad kedalaman $11-20 \mathrm{~m}$, dan alat tangkap Bubu kedalaman 21-30 m. Pengambilan data biologi rajungan meliputi pengukuran lebar dan panjang karapas rajungan dan berat rajungan serta data parameter lingkungan. Analisa hasil data yang didapat maka digunakan analisa deskriptif analitik dengan regresi sederhana untuk melihat hubungan antar variabel.

\section{Nisbah Kelamin}

Nisbah kelamin bertujuan membandingkan jumlah rajungan jantan dengan jumlah rajungan betina dari sampel yang diambil selama penelitian. Untuk membandingkan jumlah rajungan jantan dan jumlah rajungan betina dihitung dengan cara (Effendie, 2002). Kemudian untuk menentukan seimbang atau tidaknya nisbah kelamin jantan dan kelamin betina dilakukan uji Chisquare (Walpole, 1993).

\section{Hubungan Lebar Karapas dan Berat Rajungan}

Analisis pertumbuhan lebar dan berat bertujuan untuk mengetahui pola pertumbuhan rajungan di alam. Untuk mencari hubungan antara lebar dan berat total digunakan persamaan (Effendie, 2002).

\section{Tingkat Kematangan Gonad}

Pengetahuan tentang ciri-ciri tingkat kematangan gonad (TKG) mengacu dalam Modifikasi Kunsook et al., 2014.

\section{HASIL DAN PEMBAHASAN}

\section{Rajungan yang Tertangkap}

Hasil penelitian ini, didapat rajungan (Portunus pelagicus) dengan jumlah 558 ekor. 
Rajungan jantan paling banyak terdapat pada Stasiun 2 yaitu 97 ekor rajungan dan yang paling sedikit di Stasiun 1 yaitu 66 ekor. Rajungan betina terbanyak terdapat pada Stasiun 3 yaitu 155 ekor rajungan sedangkan paling sedikit di Stasiun 1 yaitu 23 ekor rajungan (Gambar1).

Hal ini dikarenakan Stasiun 3 merupakan fishing ground dari nelayan di Betahwalang yang cenderung menangkap di perairan yang dalam (kedalaman 21 -30 m). Rajungan hidup di daerah estuaria kemudian bermigrasi ke perairan bersalinitas lebih tinggi untuk proses penetasan telurnya dan rajungan muda akan kembali lagi ke estuari untuk proses pertumbuhan (Nybakken, 1986). Rajungan betina lebih menyukai substrat pasir ketika melepaskan telur, sehingga rajungan betina dewasa yang telah matang gonad akan bermigrasi ke perairan yang lebih dalam serta menempatkan diri dalam gundukan pasir untuk mengeluarkan telurnya (Sumpton et al., 1994).

Pada Stasiun 1 rajungan jantan lebih banyak tertangkap dibandingkan rajungan betina, hal ini diduga karena pada saat penelitian di lokasi Stasiun 1 sedang terjadi musim pemijahan rajungan seperti dalam pernyataan Romimohtarto dan Juwana (2005), bahwa musim pemijahan rajungan terjadi sepanjang tahun dengan puncaknya terjadi pada musim barat di bulan Desember.

\section{Nisbah Kelamin Rajungan}

Hasil penelitian Stasiun 1 diperoleh rajungan sebanyak 66 ekor rajungan jantan dan 23 ekor rajungan betina dengan nisbah kelamin 2,87: 1 . Pada Stasiun 2 didapat 97 ekor rajungan jantan dan 123 ekor rajungan betina dengan nisbah kelamin $1: 1,27$. Stasiun 3 didapat 94 ekor rajungan jantan dan 155 ekor rajungan betina dengan nisbah kelamin $1: 1,65$ (Gambar 2).

Nisbah kelamin yang ideal antara jantan dan betina adalah 1:1, namun hal ini berbeda dengan kondisi di alam yang tidak seimbang. Perbandingan jumlah jenis kelamin dapat memperkirakan keberhasilan pemijahan, selain itu dapat mempelajari struktur populasi di alam untuk menduga keseimbangannya. Berdasarkan hasil penelitian diperoleh rasio antara rajungan jantan dan betina terjadi perbedaan perbandingan rasio yang berbeda, pada Stasiun 1 lebih banyak rajungan jantan sedangkan Stasiun 2 dan 3 banyak rajungan betina. Hal tersebut diduga berkaitan dengan ketersediaan makanan dan siklus hidup rajungan terutama pada masa reproduksi. Menurut Effendie (2002) perbandingan nisbah kelamin di alam tidak akan mutlak dapat dipengaruhi oleh ketersediaan makanan, keseimbangan rantai makanan dan kepadatan populasi.

\section{Hubungan Lebar Karapas dan Berat Rajungan}

Hasil perhitungan hubungan lebar karapas rajungan dan berat rajungan, tersaji pada Gambar 3, 4 dan 5 dibawah ini dengan persamaan sebagai berikut : $W=a L^{b}$, dimana W adalah berat (gr), L adalah lebar karapas (mm), a adalah konstanta atau intercept, b adalah slope atau pola pertumbuhan/laju pertumbuhan relatif.

Koefisien regresi yang didapat dari analisis regresi yang digunakan sebagai indikator kualitas regresi, sehingga diperoleh hasil pada Stasiun 1 dengan nilai $W=$ $8,1283 L^{2,763}$ untuk rajungan jantan dan $W=$ $4,8752 L^{1,344}$ rajungan betina. Stasiun 2 nilai $W=$ $3,8019 L^{2,2463}$ untuk rajungan jantan dan $W=$ $2,0893 L^{2,2542}$ rajungan betina. Stasiun 3 nilai $W=$ $2,9512 \mathrm{~L}^{2,6346}$ untuk rajungan jantan dan $\mathrm{W}=$ 9,5499L2,6855

Hasil analisis mengenai hubungan pertumbuhan lebar karapas dan berat rajungan di perairan Betahwalang menunjukkan bahwa sifat pertumbuhan allometrik negatif. Hal tersebut diduga berkaitan dengan eksploitasi rajungan yang melewati batas optimum atau telah terjadi tangkap lebih (overfishing) berdampak pada penurunan keberhasilan pembesaran dan pemijahan rajungan. Rajungan yang tertangkap dan berukuran kecil merupakan rajungan belum matang gonad, sehingga berpotensi menurunkan keberlanjutan populasi rajungan.

Selain itu sifat pertumbuhan allometrik negatif berkaitan dengan lingkungan perairan yang tidak sesuai dengan pertumbuhan rajungan karena kerusakan habitat sehingga menyebabkan perubahan ketersediaan makanan. Abidin et al., (2014) menyatakan bahwa, pola penangkapan rajungan yang tidak terkendali akan 
mengakibatkan terjadinya penurunan potensi sumber daya rajungan.. Pertumbuhan allometrik negatif juga dipengaruhi oleh sifat makan pada saat pergantian kulit, dimana rajungan akan makan dalam jumlah sedikit dan berdampak terhadap bobot rajungan yang semakin berkurang. Menurut Josileen (2011) menyatakan bahwa rajungan kondisi (moulting) dan masa proses perkawinan cenderung berhenti untuk makan atau makan dalam jumlah sedikit.

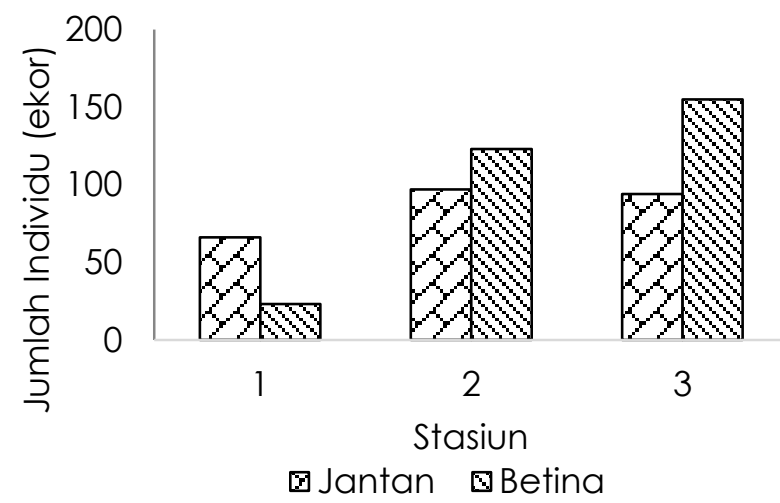

Gambar 1. Jumlah rajungan jantan dan betina yang tertangkap pada masing-masing Stasiun di Perairan Betahwalang, Demak

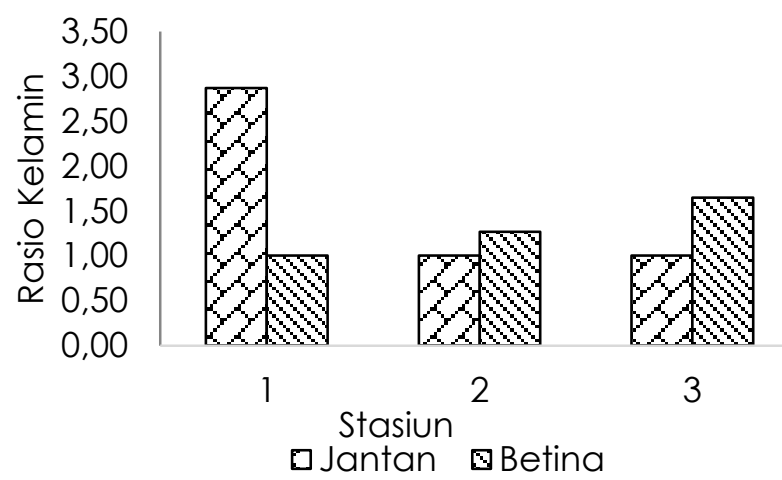

Gambar 2. Nisbah kelamin jantan dan betina yang tertangkap di Perairan Betahwalang

Pertumbuhan relatif rajungan jantan dan betina di lokasi penelitian sedikit berbeda dengan hasil pengamatan terhadap $P$. pelagicus pada penelitian sebelumnya yang dilakukan oleh di perairan Betahwalang. Dimana penelitian ini menyatakan bahwa, pola pertumbuhan rajungan jantan dan betina bersifat allometrik positif. Selain itu pola pertumbuhan rajungan pada penelitian Ernawati et al. (2014) di perairan Pati, menyatakan bahwa sifat pertumbuhan rajungan jantan dan betina adalah alometrik positif. Hal ini menunjukkan bahwa lokasi penelitian yang berbeda, telah terjadi banyak faktor perubahan diantaranya sumberdaya rajungan yang menurun, jumlah tangkapan rajungan dan faktor lingkungan seperti suhu dan salinitas. Sumpton et al., (1994) menyatakan perbedaan pola pertumbuhan dipengaruhi faktor lingkungan, suhu dan salinitas perairan dan makanan (kualitas dan ketersediaan). Selain faktor lingkungan, terdapat faktor internal seperti keturunan, seks, umur, dan penyakit berpengaruh pada pola pertumbuhan.

\section{Tingkat Kematangan Gonad}

Selama penelitian pada bulan September hingga Oktober 2016 dari ketiga Stasiun didapatkan rajungan betina 301 ekor. Dari jumlah tersebut, rajungan yang matang gonad berjumlah 271 ekor, yang terdiri dari rajungan (mature) yaitu 228 ekor dan (Spawn) yaitu 43 ekor, sedangkan belum matang gonad yaitu 30 ekor. Pada Stasiun 1 didapatkan 23 ekor rajungan betina, dalam kondisi immature $(69,57 \%)$, dan mature $(30,43 \%)$. Stasiun 2 didapatkan 123 ekor rajungan betina, dalam kondisi immature $(5 \%)$, mature $(84 \%)$ dan Spawn (10\%). Stasiun 3 didapat 155 ekor rajungan betina dalam kondisi immature (5\%), mature (76\%) dan Spawn (19\%)

Berdasarkan penelitian menunjukkan bahwa rajungan yang tertangkap pada Stasiun 1 merupakan rajungan yang belum matang gonad dengan jumlah yang lebih banyak, dikarenakan berada di daerah yang dangkal dengan kedalaman berkisar antara $1-10 \mathrm{~cm}$ dan kondisi perairan yang memiliki salinitas yang relatif rendah.

Hal tersebut berkaitan dengan pola reproduksi di daerah estuari masih bersifat belum matang gonad. Menurut Bellchambers dan Lestang (2005) sedikitnya jumlah rajungan betina dewasa yang tertangkap pada daerah estuari disebabkan oleh migrasi rajungan betina mendekati perairan laut untuk memijah. Hasil tangkapan rajungan antara Stasiun 2 dan Stasiun 3 banyak dijumpai rajungan betina yang bertelur dan matang gonad. Hal ini disebabkan daerah tangkapan rajungan yang semakin dalam perairannya berkisar antara 21 sampai $30 \mathrm{~m}$ dan juga perubahan faktor lingkungan seperti suhu maupun salinitas yang sesuai habitat rajungan betina dewasa dan rajungan yang bertelur. Menurut Sukumaran dan 

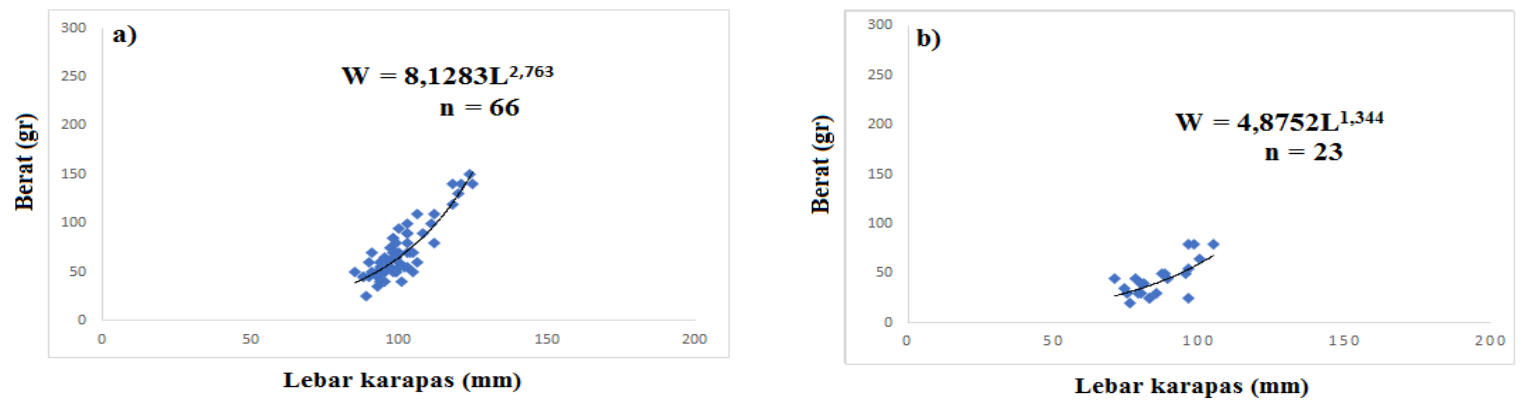

Gambar 3. Grafik Hubungan Lebar Karapas (L) dan Berat (W) Rajungan Jantan (a) dan Betina (b) pada Stasiun 1
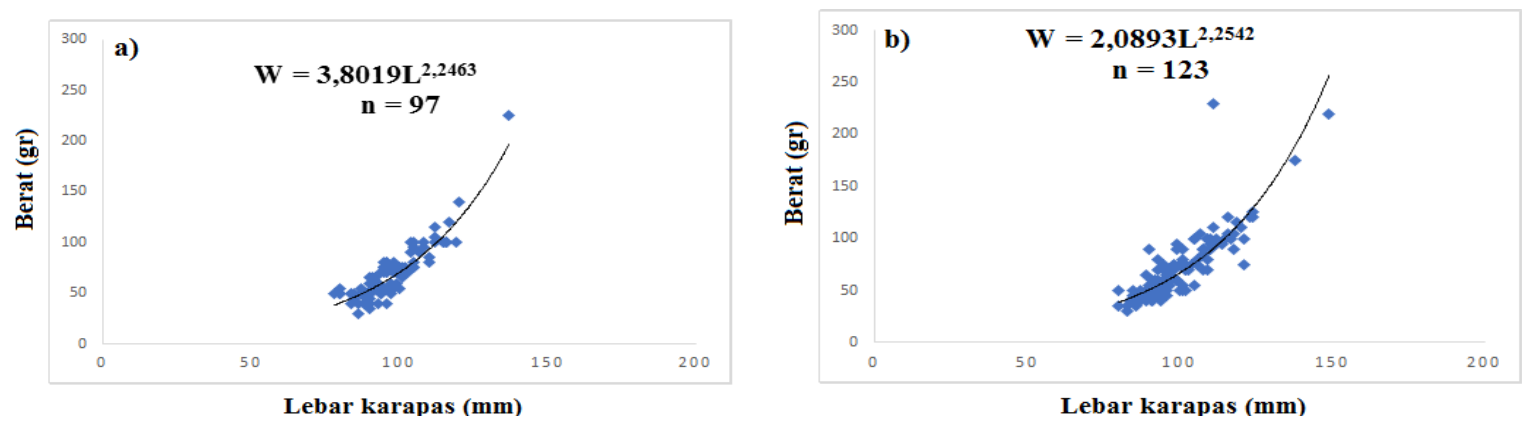

Gambar 4. Grafik Hubungan Lebar Karapas (L) dan Berat (W) Rajungan Jantan (a) dan Betina (b) pada Stasiun 2
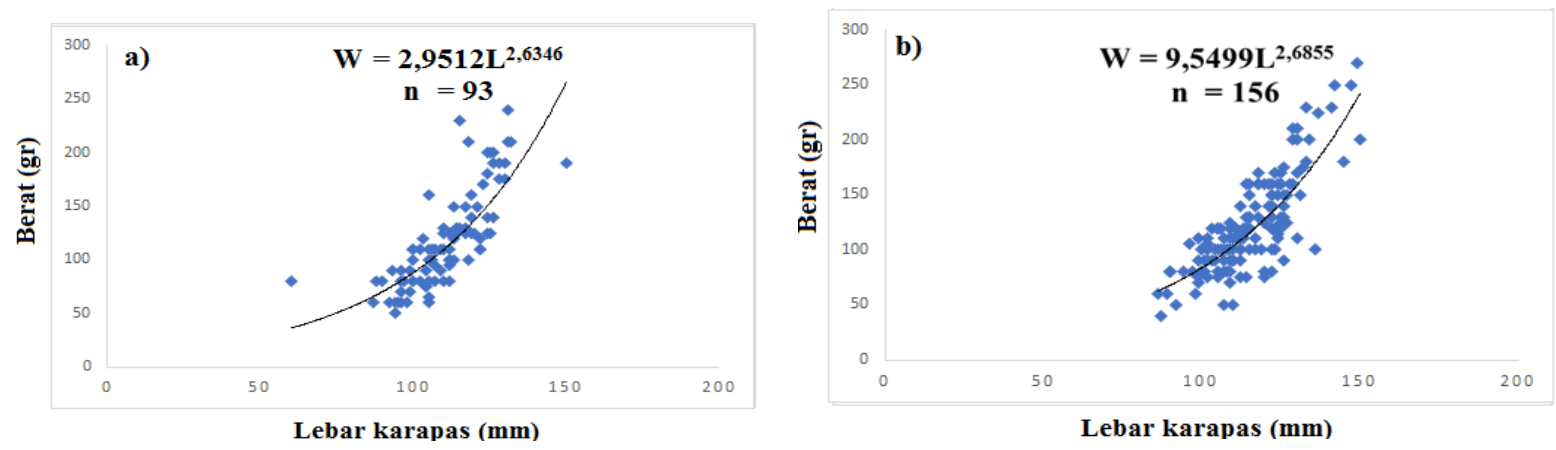

Gambar 5. Grafik Hubungan Lebar Karapas (L) dan Berat (W) Rajungan Jantan (a) dan Betina (b) pada Stasiun 3

Neelakantan (1997), rajungan berukuran lebih besar yang telah matang gonad akan bermigrasi ke perairan yang lebih dalam.

Hal ini diperkuat oleh pendapat Kangas (2000), bahwa rajungan betina yang matang gonad akan banyak terdapat pada perairan yang bersalinitas tinggi khususnya pada daerah yang berpasir agar proses penetasan telur dapat berhasil dan mendukung perkembangan larva mereka. Selain itu menurut Xiao dan Kumar (2004), bahwa rajungan betina ovigerous melakukan migrasi di perairan yang dalam dan jernih dengan pemijahan. Menurut Adam dan Sondita (2006), rajungan jantan menyenangi perairan dengan salinitas rendah (28\%) sehingga penyebarannya di sekitar perairan pantai yang relatif dangkal, sedangkan rajungan betina menyenangi salinitas tinggi (34\%o) untuk melakukan pemijahan, penyebarannya di perairan yang lebih dalam

\section{KESIMPULAN}

Nisbah kelamin rajungan jantan pada Stasiun 1 (2,87:1) lebih tinggi daripada Stasiun $2(1: 1,27)$ dan $3(1: 1,65)$. Sifat pertumbuhan 
rajungan jantan dan betina pada ketiga Stasiun menunjukkan sifat pertumbuhan allometrik negatif. Tingkat kematangan gonad rajungan Stasiun 2 (94,31\%) dan 3 (95,48\%) lebih tinggi daripada Stasiun $1(30,43 \%)$.

\section{DAFTAR PUSTAKA}

Abidin, Z., Bambang, A.N. \& Wijayanto, D. 2014. Manajemen Kolaboratif untuk Introduksi Pengelolaan Rajungan yang Berkelanjutan di Desa Betahwalang, Demak. J. Fish. Res. Utilization Manag. Technol. 4(3):29-36.

Adam, J. I., \& Sondita M.F. 2006. Model Numerik Difusi Populasi Rajungan di Perairan Selat Makassar. J. Ilmu-ilmu Perairan Perikanan Ind. 13(2):83-88.

Asosiasi Pengelolaan Rajungan Indonesia (APRI) Kab. Permalang. 2017. Pemalang Bertekad Pelihara Laut Pertahankan Kelestarian Rajungan. http://webcache. googleusercontent.com. (20 April 2017).

Bellchambers ,L.M. \& de Lestang, S. 2005. Selectivity of Different Gear Types for Sampling the Blue Swiming Crab, Portunus pelagicus L. Fish. Res. 73:21-27.

Effendie, M.I. 2002. Biologi Perikanan. Yayasan Pustaka Nusatama. Yogyakarta. $163 \mathrm{hlm}$.

Ernawati, T., Boer, M. \& Yonvitner. 2014. Biologi Populasi Rajungan (Portunus pelagicus Linnaeus) di Perairan Sekitar Wilayah Pati, Jawa Tengah. Bawal. 6(1):31-40.

Istikasari, I., A.K, Mudzakir dan D, Wijayanto. 2016. Analisis Bioekonomi Rajungan (Portunus Pelagicus) menggunakan Pendekatan Swept Area dan GordonSchaefer di Perairan Demak. Prosiding Seminar Nasional. Fakultas Perikanan dan IImu Kelautan, Universitas Diponegoro. Semarang. 433-447.

Jacoeb, A.M, Nurjanah \& Lingga, L.A.B. 2012. Karakteristik Protein dan Asam Amino Daging Rajungan (Portunus pelagicus) Akibat Pengukusan. J. Pengol. Hasil Perik. Ind. 2(15):156-163.

Josileen. J. 2011. Morphometrics and LengthWeight Relationship in the Blue Swimmer
Crab, Portunus pelagicus (Linnaeus, 1758)

(Decapoda, Brachyura) from the Mandapam Coast, India. Crustaceana 84(14):1665-1681.

Juwana, S \& Romimohtarto. 2005. Biologi Laut IImu Pengetahuan tentang Biota Laut. Djambatan, Jakarta. $26 \mathrm{hlm}$.

Kangas, M.I. 2000. Synopsis of the Biology and Exploitation of the Blue Swimmer Crab, (Portunus pelagicus Linnaeus) in Western Australia. Fisheries Research Report no. 121, 2000. Fisheries Western Australia.

Kunsook, C., Nantana, G., \& Nittharatana, P. 2014. A Stock Assessment of the Blue Swimming Crab Portunus pelagicus (Linnaeus, 1758) for Sustainable Management in Kung Krabaen Bay, Gulf of Thailand. Tropic. Life Sci. Res. 25(1):4159.

Lipcius, R.N, \& Stockhausen, W.T. 2002. Concurrent Decline of the Spawning Stock, Recruitment, Larval Abundance, and Size of the Blue Crab Callinectes sapidus in Chesapeake Bay. Mar Ecol Prog Ser. 226:45-6.

Nybakken, J.W. 1986. Biologi Laut, Suatu Pendekatan Ekologis. Gramedia. Jakarta.

Sandjaya. 2006. Metode Penelitian IImiah. PT. Gramedia. Jakarta.

Sukumaran, K.K. \& Neelakantan, B., 1997. Relative Growth and Sexual Maturity in the Marine Crabs, Portunus (Portunus) sanguinolentus (Herbst) and Portunus (Portunus) pelagicus (Linnaeus) Along the South-West Coast of India. Indian J. Fish. 43:215-223.

Sumpton,W.D., Potter, M.A. \& Smith, G.S. 1994. Reproductions and Growth of the Commercial Sand Crab (Portunus pelagicus) in Moreton Bay Queensland. Asian Fish. Sci. 7(1994):103-133.

Walpole RE. 1993. Pengantar Statistika. PT Gramedia Pustaka Jaya. Jakarta. p.4853.

Xiao, Y., \& Kumar, M. 2004. Sex ratio, and probability of sexual maturity of females at size, of the blue swimmer crab, Portunus pelagicus Linneaus, off southern Australia. Fish. Res. 68(1-3), 271-282. 